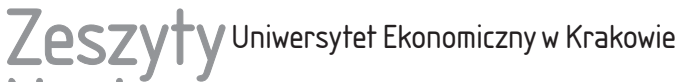 Naukowe
}

\section{Koncepcja zarządzania zasobami i usługami informatycznymi w sądach powszechnych*}

\section{Streszczenie}

W artykule została przedstawiona koncepcja dobrej praktyki informatycznej w zakresie zarządzania zasobami i usługami informatycznymi. Koncepcja dobrej praktyki powstała podczas wdrażania pilotażu dobrego zarządzania jednostkami wymiaru sprawiedliwości W ramach projektu „PWP Edukacja w dziedzinie zarządzania czasem i kosztami postępowań sądowych - case management” programu operacyjnego „Kapitał ludzki”. W artykule opisano cele dobrej praktyki, jej szczegółową zawartość oraz efekty, jakie przyniosło jej wdrożenie.

Słowa kluczowe: ITSM, dobra praktyka, sądownictwo, technologia informacyjna. Klasyfikacja JEL: M15, K00.

\section{Wprowadzenie}

Koncepcja dobrej praktyki w zakresie zarządzania zasobami i usługami informatycznymi została opracowana w ramach projektu realizowanego w latach 2013-2014 „PWP Edukacja w dziedzinie zarządzania czasem i kosztami postępowań sądowych - case management programu operacyjnego „Kapitał ludzki”.

Mariusz Grabowski, Uniwersytet Ekonomiczny w Krakowie, Wydział Zarządzania, Katedra Systemów Obliczeniowych, ul. Rakowicka 27,31-510 Kraków, e-mail: grabowsm@uek.krakow.pl

* Artykuł powstał w wyniku prac nad projektem pt. „PWP Edukacja w dziedzinie zarządzania czasem i kosztami postępowań sądowych - case management”, nr projektu POKL.05.03.00-00-012/11. 
Ramy projektu obejmowały opracowanie i wdrożenie koncepcji dobrych praktyk z zakresu IT wraz z oceną wdrożenia oraz publikacją raportów podsumowujących. Zakres projektu obejmował 60 sądów na szczeblu rejonowym, okręgowym i apelacyjnym. Opis otoczenia, warunków realizacji projektu oraz procesu tworzenia praktyk z zakresu IT został przedstawiony w artykule (Grabowski, Madej i Trąbka 2018). Celem niniejszego artykułu jest przedstawienie zaproponowanej w ramach projektu koncepcji zarządzania zasobami i usługami informatycznymi.

Doświadczenia płynące z organizacji biznesowych wskazują konieczność zarządzania zasobami informatycznymi z uwzględnieniem tzw. informatycznego modelu usługowego, który jest ściśle związany z koncepcją IT Service Management (ITSM). ITSM jest procesowo zorientowanym podejściem kliencko-centrycznym (Keel i in. 2007). Zastosowanie tej koncepcji przenosi nacisk z zarządzania zasobami na świadczenie wysokiej jakości usług dla użytkownika końcowego (Wan i Jones 2013). ITSM jest powszechnie stosowana w skali międzynarodowej (Marrone i in. 2014) oraz jest przedmiotem certyfikacji organizacyjnej (Cots, Casadesus i Marimon 2016).

W ITSM sfera organizacyjna ma zawsze charakter nadrzędny w stosunku do sfery informatycznej, co oznacza, że sfera informatyczna ma w pierwszej kolejności uwzględniać racjonalne potrzeby organizacji. Informatyczny model usługowy sprawdza się w praktyce gospodarczej, gdyż pozwala na zwiększenie wykorzystania potencjału organizacyjnego przy jednoczesnym ograniczaniu kosztów. W wyniku stosowania ITSM można osiągnąć wiele korzyści organizacyjnych. W szczególności należy do nich zaliczyć (Kneller 2013):

- dopasowanie usług informatycznych do potrzeb organizacji,

- wgląd w strukturę kosztów sfery informatycznej umożliwiający optymalizację i planowanie wydatków,

- zwiększenie skuteczności i efektywności pracy wynikające z poprawy jakości i odpowiedniego dopasowania usług informatycznych do potrzeb użytkowników,

- oszczędności finansowe wynikające z usprawnionego zarządzania zasobami i zmniejszonej pracochłonności,

- efektywne zarządzanie umożliwiające nadążanie za tempem pojawiających się zmian,

- zwiększenie zadowolenia użytkowników usług informatycznych,

- lepszy wizerunek organizacji wśród pracowników i klientów.

Metodyka Information Technology Infrastructure Library (ITIL) została uznana jako standard dla ITSM i może być zastosowana do wdrożenia zasad ładu informatycznego (Iden i Eikebrokk 2014, Kneeler 2013). Jest ona obecnie rozwijana przez fundację IT Service Management Foundation (itSMF), a aktualna wersja obejmuje pięć podręczników opisujących poszczególne fazy cyklu życia 
usług informatycznych, tj. Service Strategy, Service Design, Service Transition, Service Operation oraz Continual Service Improvement (An Introductory... 2012).

Według powszechnej opinii ITIL dedykowana jest dużym organizacjom, tj. takim, które zatrudniają kilkuset pracowników. Z wielu badań wynika, że również małe i średnie przedsiębiorstwa, tzn. takie, które liczą kilkudziesięciu pracowników, a ich oddziały informatyczne liczą po kilka osób, są zainteresowane dokonaniem zmiany modelu świadczenia usług informatycznych z technologicznego na usługowy (Ficano i in. 2013). Sądy jako instytucje zatrudniające średnio kilkaset pracowników, gdzie oddziały informatyczne liczą od kilku do kilkunastu osób, należą do tych organizacji, w których za celowe należy uznać skorzystanie z doświadczeń ITSM.

Opis otoczenia zawarty w artykule (Grabowski, Madej i Trąbka 2018) jest istotny dla zrozumienia decyzji o wyborze metodyki badawczej. Zgodnie ze wstępną oceną otoczenia projektu przewidywano, że opracowanie listy dobrych praktyk do zaproponowania kierownictwu sądów oraz ich pracownikom będzie trudnym zadaniem. Stwierdzono, że wiele rozwiązań funkcjonujących w biznesie nie znajduje zastosowania w sądach i nie powinno być brane pod uwagę, choćby ze względu na odmienność otoczenia prawnego, w którym funkcjonują jednostki gospodarcze i sądy. Lektura literatury zagranicznej potwierdziła przypuszczenia zespołu ekspertów biorących udział w projekcie, że niewiele jest badań w zakresie stosowania rozwiązań IT w zarządzaniu sądami. Nieliczne artykuły dotyczą cząstkowych rozwiązań wynikających z obowiązku stosowania wymogów prawa lokalnego, np. (Bueno i in. 2003, Luzuriaga i Cechich 2011, Gorham 2012).

Duże zróżnicowanie stopnia informatyzacji sądów stanowiło dodatkowe utrudnienie. Dotyczyło ono nie tylko zróżnicowanego poziomu infrastruktury, ale także wiedzy, doświadczenia oraz oczekiwań osób kierujących sądami w zakresie informatyzacji.

Powyższe przykłady wskazują, że sformułowanie i propozycja sprawdzonych w biznesie dobrych praktyk z zakresu IT dla sądów była działaniem wymagającym potraktowania tematu w sposób indywidualny. Specyficzne uwarunkowania sprawiły, że do realizacji projektu wykorzystano podejście metodyki badawczej action research (AR - badania w działaniu) (Baskerville i Wood-Harper 1996, Baskerville 1999, Davison, Martinsons i Kock 2004, Cole i Avison 2007, Davison, Martinsons i Ou 2012, Vries 2007), gdzie współpraca pomiędzy badaczami, tj. zespołem ekspertów, oraz pracownikami sądów stanowiła punkt wyjścia do pozyskania wiedzy naukowej. Zdobyta wiedza zaś znajdowała bezpośrednie zastosowanie w postaci opracowania praktycznych rozwiązań.

Współpraca z pracownikami sądu odbywała się w ramach spotkań organizowanych w poszczególnych jednostkach. Wizyty potwierdziły, że niektóre z dobrze znanych i stosowanych w biznesie praktyk znalazły zastosowanie także w sądach, 
stąd zasadne było określenie stopnia ich wykorzystania. W rezultacie tych obserwacji wyróżniono poziomy realizacji dobrych praktyk, przez co nawiązano do koncepcji poziomów dojrzałości (Paulk i in. 1993, COBIT 4.1... 2010).

W wyniku realizacji projektu powstała koncepcja dobrej praktyki. Informacja o tym, które z praktyk i w jakich sądach zostały skierowane do wdrożenia, została zamieszczona na końcu artykułu. Zgodnie z zastosowaną metodyką decyzja o wyborze praktyk stanowiła efekt fazy przygotowawczej.

\section{Uwarunkowania prawne oraz standardy}

Przedmiotem dobrej praktyki jest wdrożenie systematycznego podejścia do zarządzania sferą informatyczną w sądach. Należy zaznaczyć, że systematyczne podejście wynika z zapisów prawa, tj. Rozporządzenia Rady Ministrów z dnia 12 kwietnia 2012 r. w sprawie Krajowych Ram Interoperacyjności, minimalnych wymagań dla rejestrów publicznych i wymiany informacji w postaci elektronicznej oraz minimalnych wymagań dla systemów teleinformatycznych (Dz.U. nr 0 , poz. 526). Ponadto przygotowanie i wdrożenie dobrej praktyki uwzględniają obowiązujące regulacje prawne:

- Ustawa z dnia 27 lipca 2001 r. - Prawo o ustroju sądów powszechnych (Dz.U. nr 98, poz. 1070 ze zm.),

- Ustawa z dnia 18 grudnia 1998 r. o pracownikach sądów i prokuratury (Dz.U. 2011, nr 109, poz. 639 ze zm.),

- Zarządzenie Ministra Sprawiedliwości z dnia 27 czerwca 2012 r. w sprawie wprowadzenia Polityki Bezpieczeństwa Informacji Ministerstwa Sprawiedliwości i sądów powszechnych (Dz.Urz. Ministerstwa Sprawiedliwości, poz. 93),

- Zarządzenie Ministra Sprawiedliwości z dnia 12 marca 2013 r. w sprawie wskazania zamawiającego do przygotowywania i przeprowadzania postępowań o udzielenie zamówienia publicznego (Dz.Urz. Ministra Sprawiedliwości, poz. 122) oraz niektóre zasady zawarte w następujących normach i standardach:

- PN/ISO 20000-1:2007P - Technika informatyczna - Zarządzanie usługami Część 1: Specyfikacja,

- PN/ISO 20000-2:2007P - Technika informatyczna - Zarządzanie usługami Część 2: Reguły postępowania,

- IT Infrastructure Library (ITIL),

- Control Objectives for Information and Related Technology (COBIT).

Procesy biznesowe i organizacyjne współczesnych przedsiębiorstw i instytucji oparte są na sprawnym obiegu informacji, który stał się krytycznym czynnikiem ich funkcjonowania. Często nawet chwilowa niedostępność organizacyjnych systemów informacyjnych może sprawić, że jednostki nie będą w stanie nie tylko 
sprawnie działać, ale nawet funkcjonować w ogóle. Spostrzeżenie to dotyczy również polskiego sądownictwa. Sąd jest obecnie instytucją intensywnie wykorzystującą wsparcie informatyczne zarówno w działalności orzeczniczej, jak i administracyjnej.

\section{Cele dobrej praktyki w zakresie zarządzania zasobami i usługami informatycznymi}

Celem dobrej praktyki jest wdrożenie zasad dotyczących skutecznego i efektywnego zarządzania sferą informatyczną sądu. Dotyczy ona wszystkich pracowników sądu, w szczególności zaś skierowana jest do pracowników oddziału informatycznego. W prezentacji dobrej praktyki oparto się na doświadczeniu SR Katowice-Zachód w Katowicach, w którym metodyka ITIL znalazła zastosowanie. Opisywany sąd należy do grupy średnich sądów rejonowych. Oddział informatyczny sprawuje opiekę nad ok. 400 szt. zestawów komputerowych, co stanowi znaczne obciążenie pracą dla czteroosobowego zespołu informatyków. Na podstawie analizy potrzeb informacyjnych sądu oraz wymagań stawianych oddziałowi informatycznemu została podjęta decyzja o wykorzystaniu metodyki ITIL do usprawnienia metod zarządzania sferą informatyczną sądu. Zadania tego podjął się zespół oddziału informatycznego pod kierownictwem Adama Mizerskiego. Zgodnie z podstawową zasadą metodyki ITIL adapt-and-adopt zdecydowano się na wykorzystanie wybranych elementów metodyki ITIL oraz dostosowanie ich do specyfiki omawianej jednostki. Opis wdrożenia znajduje się w publikacji (Mizerski 2014).

Korzyści z wdrożenia dobrej praktyki w sądzie mogą być rozpatrywane w takich aspektach, jak:

1) aspekt organizacji pracy oddziału informatycznego. Usprawnienie osiągnięte w miarę zastępowania starego sprzętu nowym sprzętem o mniejszym stopniu zróżnicowania polega na ujednoliceniu poszczególnych składowych infrastruktury informatycznej. Unifikacja dotyczy także wykorzystywanego oprogramowania, dostosowanego do potrzeb użytkowników. Jednolita struktura sprzętowa i aplikacyjna dodatkowo zwiększy bezpieczeństwo informatycznych systemów w sądzie oraz ułatwi reagowanie na zakłócenia w jego funkcjonowaniu. Wprowadzenie metod modelowania i wizualizacji infrastruktury informatycznej zwiększy kontrolę oraz umożliwi antycypowanie zmian. Dodatkowo określenie zakresu obowiązków pod kątem świadczenia usług oddziału informatycznego (np. pierwszy i drugi poziom wsparcia w service desk) pozwoli na osiągnięcie oczekiwanej dostępności i jakości usług;

2) aspekt pracownika. Usługowy model informatyczny pozwala pracownikowi spojrzeć na informatyczne stanowisko pracy z perspektywy potrzeb informa- 
cyjnych warunkujących skuteczne i efektywne wykonywanie obowiązków, zaś o jakości usług informacyjnych przesądza efekt ich użycia. Stanowisko pracy wyposażone jest jedynie $\mathrm{w}$ niezbędne usługi, a ich działanie ujmowane jest kompleksowo (działają lub nie), a nie wycinkowo (działają ich pewne techniczne składowe). Opisany model pozwala również na lepszą komunikację pomiędzy pracownikami sądu a pracownikami oddziału informatycznego. Język, którym się porozumiewają, nie jest żargonem technicznym, lecz jest w pełni zrozumiały dla obu stron. Lepsza komunikacja pozwala na właściwe zrozumienie argumentów użytkowników odnoszących się do jakości usług informatycznych oraz informatyków, co niejednokrotnie jest pomocne w rozwiązywaniu konfliktów;

3) aspekt finansowy. Badania opisane w raporcie (Ficano i in. 2013) wskazują na 58-procentowe zwiększenie efektywności organizacyjnej firm stosujących ITSM w porównaniu z tymi, które ITSM nie stosują. Przekłada się to zarówno na zmniejszenie kosztów zarządzana sferą informatyczną, jak i kosztów pozyskania i utrzymania zasobów informatycznych. Dzięki ITSM wzrasta również efektywność pracowników pozostałych jednostek organizacji, których potrzeby informacyjne są zaspokajane przez właściwie dopasowane usługi informatycznej;

4) aspekt prawny. Wdrożenie dobrej praktyki pozwala również na spełnienie przez sąd wymogów prawa. W tym kontekście należy wymienić przede wszystkim dwa akty prawne:

- Rozporządzenie Rady Ministrów z dnia 12 kwietnia 2012 r. w sprawie Krajowych Ram Interoperacyjności, minimalnych wymagań dla rejestrów publicznych i wymiany informacji w postaci elektronicznej oraz minimalnych wymagań dla systemów teleinformatycznych (Dz.U. nr 0, poz. 526),

- Zarządzenie Ministra Sprawiedliwości z dnia 27 czerwca 2012 r. w sprawie wprowadzenia Polityki Bezpieczeństwa Informacji Ministerstwa Sprawiedliwości i sądów powszechnych (Dz.Urz. Ministra Sprawiedliwości, poz. 93).

\section{Podstawowe elementy procesu formułowania dobrej praktyki w zakresie zarządzania zasobami i usługami informatycznymi}

\subsection{Zdefiniowanie założeń, zakresu i funkcji dobrej praktyki}

Zmiana organizacyjna polegająca na zastosowaniu koncepcji ITSM może być (i na ogół jest) przedsięwzięciem złożonym, długookresowym oraz angażującym znaczne środki finansowe. W celu uniknięcia nieuzasadnionych kosztów oraz błędów wdrożeniowych metodyka ITIL propaguje zasadę adapt-and-adopt, czyli wybranie tylko tych elementów biblioteki, które są właściwe dla organizacji, oraz dostosowanie ich do jej specyfiki. Zaleca się, aby wdrożenie przebiegało stop- 
niowo, czyli tak, aby organizacja mogła dojść do poziomu docelowego w długim okresie.

Na każdym etapie wdrożenia należy preferować małe zmiany z ich ewentualnym późniejszym rozszerzeniem. Wiele wdrożeń rozwiązań ITSM zakończyło się niepowodzeniem z uwagi na przeszacowanie zakresu zmian.

Dobra praktyka zakłada wykorzystanie istniejącego sprzętu oraz oprogramowania open source (lub innego darmowego oprogramowania bądź wcześniej zakupionego oprogramowania komercyjnego), co w praktyce oznacza ograniczenie wydatków związanych z wdrożeniem jedynie do kosztów osobowych. Wartościowe okazały się doświadczenia SR Katowice-Zachód w Katowicach, które uwzględniają specyfikę sądu rejonowego, tj. zarządzanie złożoną strukturą informatyczną oraz stosunkowo skromne zasoby osobowe działu informatycznego.

\subsection{Faza przygotowawcza}

Faza przygotowawcza ma na celu określenie zakresu wdrożenia i jest procesem składającym się z czterech etapów: wstępnej oceny poziomu dojrzałości, weryfikacji poziomu dojrzałości, określenia docelowego poziomu dojrzałości oraz wyboru metod i narzędzi koniecznych do osiągnięcia poziomu docelowego. Proces definiowania zakresu wdrożenia zaprezentowano na rys. 1.

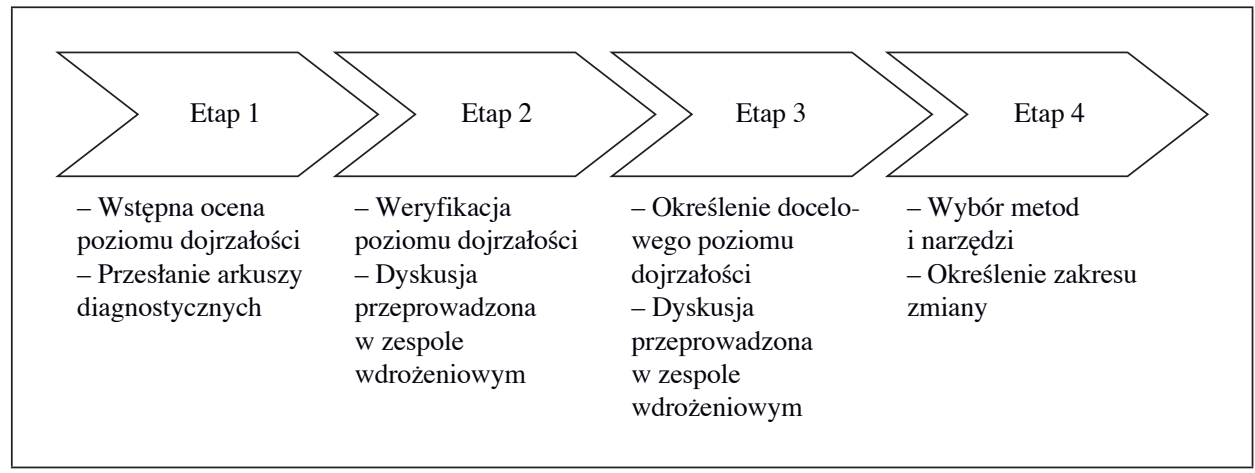

Rys. 1. Proces definiowania zakresu wdrożenia

Źródło: opracowanie własne.

Arkusze diagnostyczne rozesłane do sądów biorących udział w pilotażu miały na celu określenie poziomu dojrzałości organizacji w stosowaniu omawianej dobrej praktyki (zgodnie z tabelą 1). Oznacza to, że etap 1 fazy przygotowawczej został już ukończony. Przesłane odpowiedzi traktowane są jako ocena wstępna. $\mathrm{Na}$ etapie wdrożenia należy dokonać weryfikacji oceny poziomu dojrzałości, 
a następnie określić poziom docelowy. W niektórych przypadkach może się okazać, że pomimo spełnienia wymagań poziomu wyższego nie są spełnione wymogi poziomu niższego. Weryfikacja istniejącego poziomu dojrzałości oraz określenie poziomu docelowego determinują wybór odpowiedniego zestawu narzędzi, który ma na celu dopasowanie praktyki do specyfiki sądu. Proces dopasowania wdrażanej praktyki powinien mieć formę dyskusji przeprowadzonej w zespole wdrożeniowym (w którego skład oprócz przedstawicieli firmy wdrożeniowej wchodzą również pracownicy sądu) oraz zostać zakończony kompromisem odnośnie do zakresu dokonywanych zmian.

Tabela 1. Poziomy dojrzałości dobrej praktyki pn. ,zarządzanie zasobami i usługami informatycznymi"

\begin{tabular}{|c|l|l|}
\hline Nr poziomu & Nazwa poziomu & \multicolumn{1}{|c|}{ Wymagania } \\
\hline I & Początkowy & $\begin{array}{l}\text { Ujednolicenie i standaryzacja sprzętu komputerowego } \\
\text { - komputerów stacjonarnych, przenośnych, serwerów, } \\
\text { sprzętu drukującego, skanerów itd. (ustalenie parame- } \\
\text { trów urządzeń dla poszczególnych grup użytkowników) } \\
\text { oraz ustalanie odpowiedniej wielkości zamówienia }\end{array}$ \\
\hline II & $\begin{array}{l}\text { Powtarzalny, } \\
\text { lecz intuicyjny }\end{array}$ & $\begin{array}{l}\text { Standaryzacja typów sprzętu (np. komputer do obsługi } \\
\text { sekretariatu, komputer do obsługi sali rozpraw). Wyko- } \\
\text { rzystanie list kontrolnych przy konfiguracji urządzeń } \\
\text { i instalacji oprogramowania }\end{array}$ \\
\hline III & Zdefiniowany & $\begin{array}{l}\text { Automatyzacja instalacji i konfiguracji oprogramowania } \\
\text { (np. wykorzystanie Windows Deployment Services - } \\
\text { WDS, Windows Server Update Services - WSUS, Group } \\
\text { Policy Objects - GPO, System Center Configuration } \\
\text { Manager - SCCM) }\end{array}$ \\
\hline IV & $\begin{array}{l}\text { Kontrolowany } \\
\text { i mierzalny }\end{array}$ & $\begin{array}{l}\text { Wykorzystanie narzędzi do opisu i (lub) monitorowania } \\
\text { infrastruktury informatycznej (np. nVision, Spiceworks) }\end{array}$ \\
\hline V & Zoptymalizowany & Implementacja wybranych elementów ITIL \\
\hline
\end{tabular}

Źródło: opracowanie własne.

W tabeli 1 zaprezentowano poziomy dojrzałości dobrej praktyki zarządzania zasobami i usługami informatycznymi. W dalszej części opracowania zostaną opisane metody i narzędzia informatyczne wykorzystywane na jej poszczególnych poziomach.

\subsection{Określenie poziomów dojrzałości dobrej praktyki}

Poziom I - poczqtkowy. Strukturą informatyczną o dużym stopniu zróżnicowania (tzn. składającą się z wielu typów komponentów sprzętowych i programi- 
stycznych) trudno jest skutecznie i efektywnie zarządzać, dlatego należy dążyć do jej ujednolicenia i uproszczenia. Działania wynikające z Zarządzenia Ministra Sprawiedliwości z dnia 12 marca 2013 r. w sprawie wskazania zamawiającego do przygotowywania i przeprowadzania postępowań o udzielenie zamówienia publicznego, udzielania zamówień oraz zawierania umów ramowych na rzecz sądów powszechnych, skutkujące utworzeniem centrum zakupowego dla sądownictwa działającego w Sądzie Apelacyjnym w Krakowie, są ważnymi działaniami na rzecz ujednolicenia infrastruktury sprzętowej. Podejmując decyzje zakupowe, sądy powinny brać pod uwagę liczbę oraz przeznaczenie sprzętów, np. na sale rozpraw, do sekretariatu, dla orzeczników. W praktyce ww. działania ograniczają się do przystosowania następujących procedur:

- ustalenie parametrów urządzeń dla grup użytkowników, polegające na wyborze odpowiedniego zestawienia sprzętów dostępnych w centrum zakupowym dla sądownictwa na dany okres,

- ustalenie minimalnej liczby sprzętów z poszczególnych kategorii,

- przesunięcie zakupu na następny okres w przypadku, gdy wymiana sprzętu w danym okresie nie jest krytyczna z punktu widzenia efektywności pracy.

Pomimo pewnych trudności w unifikacji infrastruktury informatycznej, takich jak ustawa o prawie zamówień publicznych, która uniemożliwia ujednolicenie sprzętu do jednego modelu czy jednego producenta, oraz praktyka wydawania środków budżetowych, która często uniemożliwia ich przesuwanie na następne okresy, należy starać się dążyć do maksymalizacji liczby jednorodnych jednostek. Konsekwentne stosowanie powyższych zasad będzie skutkować zwiększaniem jednorodności infrastruktury informatycznej.

Poziom II - powtarzalny, lecz intuicyjny. Kolejnym krokiem jest standaryzacja procedur konfiguracji sprzętu i instalacji oprogramowania. Podstawową metodą jest stworzenie list kontrolnych opisujących ustawienia parametrów konfiguracyjnych dla poszczególnych rodzajów sprzętu oraz oprogramowania. Na drugim poziomie wprowadza koncepcję usługowego modelu informatycznego. W modelu tym użytkownik jest zainteresowany przede wszystkim możliwościami stanowiska roboczego pod względem skutecznej i efektywnej realizacji postawionych przed nim zadań, a nie parametrami technicznymi sprzętu i oprogramowania. Listy kontrolne dla poszczególnych typów sprzętu powinny uwzględniać jego przeznaczenie.

Poziom III - zdefiniowany. Aktualizacja i konserwacja infrastruktury informatycznej na podstawie zdefiniowanych na poprzednim poziomie list kontrolnych jest zadaniem pracochłonnym i czasochłonnym (sprawdzanie poszczególnych punktów listy kontrolnej, udanie się do miejsca, w którym znajduje się konfigurowana jednostka) oraz narażonym na powstawanie błędów. Dlatego tam, gdzie jest to możliwe, należy stosować automatyczne procedury instalacyjne i aktualizacyjne. 
W środowisku MS Windows, stanowiącym podstawową platformę systemową w polskich sądach, istnieje wiele metod pozwalających na realizację tego zadania. Należy tutaj przede wszystkim wymienić: Group Policy Objects (GPO), Windows Deployment Services (WDS), Windows Server Update Services (WSUS) oraz System Center Configuration Management (SCCM). Rozwiązania środowiska MS Windows pozwalają na dokonanie modyfikacji ustawień środowiska systemowego lub eliminację awarii poprzez wykorzystanie pulpitu zdalnego. Do tej grupy rozwiązań można również zaliczyć komercyjne oprogramowanie innych firm, takie jak np. IDEL Administration.

Poziom IV - kontrolowany i mierzalny. Kolejnym krokiem jest monitorowanie oraz wizualizacja infrastruktury informatycznej w czasie rzeczywistym. Do funkcjonalności tu omawianych należy zaliczyć:

- zdalną inwentaryzację komponentów sprzętowych i programowych (stacji roboczych, urządzeń sieciowych, serwerów, systemów, serwisów i aplikacji),

- śledzenie aktywności użytkowników, w szczególności monitorowanie używanych aplikacji, dostępu do Internetu, drukowania oraz użycia urządzeń zewnętrznych,

- monitorowanie bezpieczeństwa i ruchu sieciowego,

- przewidywanie i lokalizowanie awarii pozwalające na wczesne przeprowadzenie akcji korekcyjnych,

- wizualizację poszczególnych komponentów infrastruktury sprzętowej i aplikacyjnej na interaktywnych mapach.

Istnieje wiele rozwiązań informatycznych pozwalających na realizację powyższych zadań, różniących się od siebie zakresem funkcjonalności oraz ceną. Informacja o poszczególnych komponentach infrastruktury jest gromadzona w centralnej bazie danych systemu monitorującego przez skanowanie infrastruktury lub jest dostarczana do systemu centralnego za pośrednictwem specjalnych programów (tzw. agentów) uruchamianych na monitorowanych komponentach. Do odpłatnych systemów można zaliczyć: Axence Navision, NetCrunch, LOG System, Ewida Audit, GFI LanGuard. Istnieją również w pełni funkcjonalne darmowe programy, spośród których na szczególną uwagę zasługują Nagios Open Source i Spiceworks.

Poziom V-zoptymalizowany. Poziom piąty stanowi najbardziej zaawansowany etap wdrożenia dobrej praktyki i jest związany z implementacją wybranych elementów biblioteki ITIL. Chociaż ITIL nie narzuca zakresu ani kolejności wdrażania poszczególnych elementów biblioteki, to doświadczenia wskazują na konieczność rozpoczęcia od stworzenia katalogu usług informatycznych oraz CMDB - bazy danych konfiguracji zarządzanego środowiska informatycznego.

Proces tworzenia katalogu usług składa się z następujących etapów (Mizerski 2014): 
- stworzenie opisu usług informatycznych wykorzystywanych w sądzie; przykładowo w SR Katowice-Zachód zidentyfikowano 57 usług realizowanych przez 40 różnych systemów,

- określenie, które usługi informatyczne są używane przez poszczególne jednostki organizacyjne sądu,

- określenie komponentów technicznych niezbędnych do wykonania usług,

- zdefiniowanie macierzy powiązań pomiędzy usługami informatycznymi a niezbędnymi do ich świadczenia komponentami technicznymi.

Stworzenie katalogu usług informatycznych pozwala na uzyskanie informacji nie tylko odnośnie do wykonywanych usług, ale również wzajemnych uwarunkowaniach pomiędzy usługami i technicznymi komponentami je realizującymi. Ułatwia to identyfikację krytycznych elementów infrastruktury informatycznej i antycypowanie pożądanych kierunków jej modyfikacji. Baza CMDB powinna zawierać wszystkie istotne informacje dotyczące konfiguracji środowiska informatycznego (wraz z jego zmianami) oraz procedury postępowania dla zgłoszeń serwisowych. Istnieje wiele narzędzi implementujących CMBD. Rozwiązania komercyjne są na ogół drogie i przeznaczone dla bardzo dużych organizacji. Istnieją również rozwiązania nieodpłatne, np. iTop, lecz ich złożoność może również być przeszkodą w implementacji ITSM w sądzie. W SR Katowice-Zachód w Katowicach jako platformę do implementacji CMDB wykorzystano oprogramowanie MediaWiki, głównie z uwagi na łatwość zespołowego tworzenia zawartości, możliwość tworzenia repozytoriów zawierających zarówno elementy opisu procedur, jak i elementy oprogramowania i (lub) sterowników niezbędnych do działań wynikających ze zgłoszenia serwisowego. Dodatkowym atutem MediaWiki jest jej hipertekstowość, tj. możliwość dowolnego łączenia poszczególnych komponentów. Właściwie określony katalog usług informatycznych oraz CMDB pozwalają na zarządzanie sferą informatyczną organizacji, tj. zarządzanie uprawnieniami dostępu oraz wersjami i wdrożeniami. Ograniczanie i kontrolowanie przyznawania i korzystania z przywilejów (również w odniesieniu do usług informatycznych) oraz wdrożenie praktyk prowadzących do kontrolowania i dokumentowania zmian w systemach i środkach przetwarzania informacji są określone przez normę PN-ISO/IEC 27001:2007.

Do darmowych narzędzi wspomagających wdrażanie elementów ITSM można zaliczyć aplikację ADOit CE pozwalającą na modelowanie korporacyjnej struktury informacyjnej na czterech poziomach: procesów organizacyjnych, systemów informacyjnych, danych oraz technologii, łącząc w ten sposób koncepcje katalogu usług z CMDB oraz oprogramowanie iTop pozwalające na wdrożenie poszczególnych elementów biblioteki ITIL. Jednym z najczęściej implementowanych rozwiązań ITSM jest service desk, czyli zbiór zdefiniowanych procedur postępowania w przypadku pojawiania się zgłoszeń serwisowych. Oprogramowanie reali- 
zujące funkcje service desk pozwala na zdalną rejestrację zgłoszeń serwisowych w postaci tzw. biletów (każde zgłoszenie ma swój numer), co umożliwia służbom informatycznym ich kategoryzację i nadawanie priorytetów. Rozwiązania tego typu często jednak przyjmują formę odhumanizowanej komunikacji ze służbami informatycznymi i są negatywnie odbierane przez pracowników organizacji.

Doświadczenia SR Katowice-Zachód w Katowicach wskazują konieczność ostrożnego podejścia do realizacji funkcji service desk. W organizacji tej celowo nie zastosowano rozwiązania opartego na elektronicznym systemie biletowym, ale z uwagi na uwarunkowania lokalowe sądu zdefiniowano dwa pojedyncze punkty kontaktu (single point of contact - SPOC) realizujące zgłoszenia telefoniczne oraz dwie linie wsparcia dla użytkowników. Pierwsza z nich zajmuje się zgłoszeniami prostymi i powtarzalnymi, natomiast druga rozwiązuje problemy, które nie mogły zostać rozwiązane przez pierwszą. Personel oddziału informatycznego jest również wyczulony na kwestie doskonalenia umiejętności interpersonalnych dotyczących komunikowania się z użytkownikami usług informatycznych.

\subsection{Zalecenia końcowe}

Przedstawioną koncepcję modeli dojrzałości należy traktować jako punkt odniesienia. Rozwiązania proponowane na jej poszczególnych poziomach mogą być dowolnie dopasowywane do potrzeb organizacji. W praktyce może to w szczególności oznaczać, że niektóre rozwiązania poziomów wyższych mogą być stosowane pomimo niezaimplementowania pewnych rozwiązań poziomów niższych. W każdym przypadku o ostatecznym kształcie zakresu zmiany powinny decydować rzeczywiste potrzeby organizacji.

Zaleca się, aby każde z działań podjętych podczas implementacji praktyki było formalnie dokumentowane, co pozwoli uchronić wypracowane metody i narzędzia przed ich utratą w przypadku zmiany personelu oraz stanowić będzie dowód dostosowania infrastruktury informatycznej do wymogów określonych przepisami prawa. Cennym narzędziem pozwalającym na implementację usługowego modelu informatycznego jest wyposażenie każdego stanowiska roboczego w zwięzłą instrukcję procedury korzystania z systemu oraz działań w przypadku sytuacji awaryjnych. Ma ona znaczenie zwłaszcza w przypadku przyjmowania do pracy nowych pracowników.

Docelowo implementacja usługowego modelu świadczenia usług informatycznych powinna uwzględniać koordynację działań w ramach całej apelacji. Liczba pracowników wchodzących w skład personelu informatycznego zatrudnionego w poszczególnych sądach apelacji pozwala na uzyskanie efektu skali oraz większą specjalizację w organizacji działań drugiej linii wsparcia, rozwiązującej problemy o większym stopniu skomplikowania. 


\section{Wnioski z wdrożenia dobrej praktyki w zakresie zarządzania zasobami i usługami informatycznymi}

Dobra praktyka „Zarządzanie zasobami i usługami informatycznymi” została wdrożona w 23 sądach: w 22 w ramach pilotażu podstawowego i w 1 sądzie w ramach pilotażu uzupełniającego (Badanie ewaluacyjne... 2015). Wśród sądów, które wybrały dobrą praktykę, był m.in. Sąd Rejonowy dla Łodzi-Widzewa oraz Sąd Okręgowy w Jeleniej Górze.

Harmonogram wdrażania oraz poziom zaawansowania prac w poszczególnych sądach pilotażowych zamieszczone zostały w (Raporcie całościowym... 2014).

Z opublikowanych raportów i informacji uzyskanych podczas współpracy autora z firmą wdrażającą można wyciągnąć końcowe wnioski. Wdrożenie dobrej praktyki miało pozytywny wpływ na proces zarządzania zasobami informatycznymi. Wśród sądów, które ją zaimplementowały, dokonano m.in. następujących usprawnień:

- wdrożono elektroniczny system service desk,

- wdrożono procedury automatycznej instalacji oprogramowania,

- wdrożono oprogramowanie do monitorowania zasobów informatycznych.

Wdrożenie dobrej praktyki było ponadto okazją do dokonania audytu istniejących rozwiązań informatycznych funkcjonujących w sądzie.

Po zakończonym wdrożeniu, na podstawie przeprowadzonych ankiet i wywiadów z pracownikami sądów, wskazano najważniejsze zalety i ograniczenia dobrej praktyki oraz oceniono jej efekty.

Do głównych zalet dobrej praktyki należą:

- możliwość bieżącej inwentaryzacji sprzętu i oprogramowania,

- usprawnienie procesu zarządzania zasobami informatycznymi,

- wyeliminowanie problemów dotyczących konfiguracji sprzętu komputerowego.

Do ograniczeń dobrej praktyki zaliczono:

- czasochłonność wdrożenia,

- niewystarczające dopasowania do specyfiki określonego sądu.

Za najważniejsze efekty wdrożenia dobrej praktyki uznano:

- usprawnienie pracy sądu dzięki wsparciu pionu orzeczniczego, usprawnieniu pracy sekretariatu oraz poprawie przepływu informacji w sądzie,

- lepsze dopasowanie usług informatycznych do potrzeb organizacji oraz lepszy wizerunek organizacji wśród pracowników i klientów,

- optymalne wykorzystanie zasobów i usług informatycznych.

Opracowywanie koncepcji dobrych praktyk i współpraca ze środowiskiem sądowym były interesującym doświadczeniem, zaś wybór metody AR do zaproponowania dobrej praktyki zarządzania w sądach, jako metody pionierskiej, okazał 
się trafny. W celu kontynuacji badań zespół realizujący projekt prowadzi prace przygotowawcze, które pozwolą na ocenę efektów wdrożenia dobrych praktyk informatycznych.

\section{Literatura}

Badanie ewaluacyjne pilotażu wdrażania dobrego zarzqdzania jednostkami wymiaru sprawiedliwości $w$ ramach projektu „PWP Edukacja $w$ dziedzinie zarzqdzania czasem i kosztami postępowań sq̨dowych - case management". Raport końcowy (2015), ASM - Centrum Badań i Analiz Rynku, Kutno.

Baskerville R.L. (1999), Investigating Information Systems with Action Research, Communications of the Association for Information Systems, vol. 2, Article 19, http://aisel. aisnet.org/cais/vol2/iss1/19 (data dostępu: 15.09.2014).

Baskerville R.L., Wood-Harper A.T. (1996), A Critical Perspective on Action Research as a Method for Information Systems Research, „Journal of Information Technology”, vol. 11, nr 3, https://doi.org/10.1080/026839696345289.

Bueno T.C.D., Bortolon A., Hoeschl H.C., Mattos E.S., Santos C.S., Theiss I. (2003), Using $R B C$ to Classify Judicial Petitions on e-Court, Proceedings of the 9th international conference on Artificial intelligence and law, ICAIL '03, June 24-28, Edinburgh, Scotland, UK.

COBIT 4.1. Metodyka. Cele kontrolne. Wytyczne zarzq̨zenia. Modele dojrzałości (2010), IT Governance Institute, Stowarzyszenie Audytu, Bezpieczeństwa i Kontroli Systemów Informacyjnych ISACA, Warszawa.

Cole M., Avison D. (2007), The Potential of Hermeneutics in Information Systems Research, „European Journal of Information Systems”, vol. 16, nr 6, 820-833, https://doi. org/10.1057/palgrave.ejis.3000725.

Cots S., Casadesus M., Marimon F. (2016), Benefits of ISO 20000 IT Service Management Certification, „Information Systems and e-Business Management”, vol. 14, nr 2, https://doi.org/10.1007/s10257-014-0271-2.

Davison R.M., Martinsons M.G., Kock N. (2004), Principles of Canonical Action Research, „Information Systems Journal”, vol. 14, nr 1, https://doi.org/10.1111/j.1365 $-2575.2004 .00162 . x$.

Davison R.M., Martinsons M.G., Ou C.X.J. (2012), The Roles of Theory in Canonical Action Research, „MIS Quarterly”, vol. 36, nr 3, https://doi.org/10.2307/41703480.

Ficano C., Förster C., Grabowski M., Hertweck D., Hiebler K., Hoffmann C., Karagiannis D., Küller P., Miron E.T., Silhar K., Soja P., Vágner A., Vécsi B., Vogt M., Walterová I., Zajac A. (2013), Bringing IT Service Management and Innovation to SMEs in Central Europe, INNOTRAIN IT - Innovation Training IT Central Europe, Public final report of the project INNOTRAIN IT, MFG Innovation Agency for ICT and Media Baden-Württemberg, Germany, https://www.hs-heilbronn.de/5076380/ INNOTRAIN-IT-Public-Final-Report-Web.pdf (data dostępu: 5.09.2017).

Gorham U. (2012), State Courts, e-filing, and Diffusion of Innovation: A Proposed Framework of Analysis, Proceedings of the 13th Annual International Conference on Digital Government Research, dg.o '12, June 04-07, College Park, MD, USA.

Grabowski M., Madej J., Trąbka J. (2018), Koncepcja metodyki projektowania i wdrażania dobrych praktyk informatycznych dla sqdów powszechnych, ,Zeszyty Naukowe 
Uniwersytetu Ekonomicznego w Krakowie”, nr 4(976), https://doi.org/10.15678/ ZNUEK.2018.0976.0413.

Iden J., Eikebrokk T.R. (2014), Using the ITIL Process Reference Model for Realizing IT Governance: An Empirical Investigation, ,Information Systems Management”, vol. 31, nr 1, https://doi.org/10.1080/10580530.2014.854089.

Informatyzacja postępowania cywilnego. Teoria i praktyka (2016), red. K. Flaga-Gieruszyńska, J. Gołaczyński, D. Szostek, Seria Monografie Prawnicze, C.H. Beck, Warszawa.

An Introductory Overview of ITIL® 2011 (2012), eds Cartlidge A., Lillycrop M., The IT Service Management Forum, https://www.tsoshop.co.uk/gempdf/itSMF_An_Introductory_Overview_of_ITIL_V3.pdf (data dostępu: 5.09.2017).

Keel A.J., Orr M.A., Hernandez R.R., Patrocinio E.A., Bouhard J. (2007), From a Technology-oriented to a Service-oriented Approach to IT Management, ,IBM Systems Journal", vol. 46, nr 3, https://doi.org/10.1147/sj.463.0549.

Kneeler M. (2013), Executive Briefing: the Nenefits of ITIL $\AA$, Axelos, https://www.axelos.com/case-studies-and-white-papers/executive-briefing-the-benefits-of-itil (data dostępu: 5.09.2017).

Luzuriaga, J.M., Cechich A. (2011), Electronic Notification of Court Documents: A Case Study, Proceedings of the 5th International Conference on Theory and Practice of Electronic Governance, ICEGOV '11, September 26-28, Tallinn, Estonia.

Marrone M., Gacenga F., Cater-Steel A., Kolbe L. (2014), IT Service Management: A Cross-national Study of ITIL Adoption, „Communications of the Association for Information Systems”, vol. 34, Article 49, https://doi.org/10.17705/1cais.03449.

Mizerski A. (2014), Usługowy model zarzqdzania pracq Oddziału Informatycznego z. wykorzystaniem dobrych praktyk biblioteki ITIL (w:) Metodyka zarzqdzania jednostkami wymiaru sprawiedliwości. Studium przypadku na przykładzie Sadu Rejonowego Katowice-Zachód w Katowicach, red. K. Hejosz, Krajowa Szkoła Sądownictwa i Prokuratury, Kraków, http://www.kssip.gov.pl/sites/default/files/metodyka_zarzadzania_internet.pdf (data dostępu: 5.09.2017).

Paulk M.C., Weber C.V., Curtis B., Chrissis M.B. (1993), Capability Maturity Model for Software (Version 1.1), Technical Report CMU/SEI-93-TR-024 ESC-TR-93-177, February, Software Engineering Institute, Carnegie Mellon University, Pittsburgh, PA, https://resources.sei.cmu.edu/asset_files/TechnicalReport/1993_005_001_16211.pdf (data dostępu: 13.04. 2018).

Raport całościowy z wdrożenia za okres od 1 grudnia 2013 r. do 24 października 2014 r. (2014), oprac. WYG International, WYG Consulting, WYG PSDB, Uniwersytet Ekonomiczny w Krakowie, Instytut Allerhanda na zlecenie Krajowej Szkoły Sądownictwa i Prokuratury, http://www.efs2007-2013.gov.pl/Dokumenty (data dostępu: grudzień 2016).

Vries E. (2007), Rigorously Relevant Action Research in Information Systems, University of Amsterdam, The Netherlands, Sprouts: Working Papers on Information Systems, 7(4), http://sprouts.aisnet.org/7-4 (data dostępu: 19.04.2014).

Wan J., Jones J.D. (2013), Managing IT Service Management Implementation Complexity: From the Perspective of the Warfield Version of Systems Science, Enterprise Information Systems, vol. 7, nr 4, https://doi.org/10.1080/17517575.2011.625572. 


\section{IT Resource and Service Management in Common Courts}

(Abstract)

The paper describes good practice in IT resource and service management, developed during the implementation of a pilot study of good governance of judiciary units in the project "PWP Education in the time and cost management of judicial proceedings - case management" of the Human Capital Programme. The paper presents a detailed description of good practice objectives and the effects of their implementation.

Keywords: ITSM, good practice, judiciary, information technology. 